\title{
Fytobentos a makrozoobentos pražských potoků s př́rodními veřejnými koupališti
}

\section{LADISLAV HAVEL, JAN ŠŤASTNÝ, BLANKA DESORTOVÁ}

Klíčová slova: pražské potoky - př́rodní veřejná koupaliště - fytobentos - makrozoobentos

\section{SOUHRN}

Sledování kvality vody pražských potoků s přírodními veřejnými koupališti v letech 2018 až 2019 (v rámci operačního programu Praha - pól růstu II) bylo zároveň doplněno o sledování a hodnocení biologických složek ekosystému: společenstev fytobentosu a makrozoobentosu. Výhodou je, že stav těchto společenstev odráží kolísání kvality vody v profilech po delší období (na rozdíl od okamžitého stavu při odběru vzorků vody).

Z výsledků sledování makrozoobentosu vyplývá, že toto společenstvo vykazuje nejvyšší abundanci a druhovou diverzitu v úsecích potoků s nejpřirozenějšími morfologickými podmínkami (prírodní koryta potoků Litovicko-Šáreckého potoka pod nádrží Džbán a Botiče nad i pod nádrží Hostivař). I tato společenstva však při kombinaci vlivů prostředí (morfologie toku, kvalita vody) svým stupněm saprobity odpovídají horší beta-mesosaprobitě. Naopak ve společenstvech fytobentosu žádný významnější rozdíl (až na hojnější výskyt vláknitých forem řas $\vee$ prírodních korytech) mezi prirozenými a umělými profily zjištěn nebyl. Pro vesměs přizpůsobivé rassy (zejména rozsivky), které v uvedených profilech dominují, se tedy zdá být klíčovým faktorem spíše chemismus vody než např. mikrotopografie dna.

Při předpokládané (budoucí) revitalizaci regulovaných a vydlážděných potoků je nutno zahrnout i úpravu jejich morfologie a substrátu dna a zároveň věnovat značnou pozornost kvalitě príitékající vody.

\section{ÚVOD}

V letech 2018 a 2019 byla v rámci operačního programu Praha - pól růstu II sledována kvalita vody potoků, v jejichž povodí se nacházejí nádrže určené k rekreaci: Motolský potok se soustavou tři retenčních nádrží R1-R3 (oficiální veřejné koupaliště je v nádrži R2, ale využívána je i nádrž R1), Litovicko-Šárecký potok s nádrží Džbán, Vestecký a Kunratický potok s rybníkem Šeberák (v průběhu roku 2019 vypuštěn a odtěženy sedimenty), Botič s nádrží Hostivař. Výsledky z let 2018-2019 jsou uvedeny v [1, 2]. Protože odběr vzorků vody vždy zobrazuje pouze okamžitý stav kvality $v$ daném profilu, bylo vzorkování doplněno o sledování společenstev fytobentosu a makrozoobentosu. Výhoda zařazení těchto ukazatelů tkví v tom, že jejich stav „integruje“ vliv kolísání kvality vody na obě společenstva $v$ daném profilu za dobu mezi odběry.

\section{SLEDOVANÉ LOKALITY}

Vzorky fytobentosu a makrozoobentosu byly odebírány vždy z prítoků a odtoků potoků do a z príslušných nádrží určených k rekreaci: Motolský potok se soustavou tří retenčních nádrží R1-R3, Litovicko-Šárecký potok s nádrží Džbán, Vestecký a Kunratický potok s rybníkem Šeberák, Botič s nádrží Hostivař. Odběrové profily jsou vyznačeny na obr. 1-4.

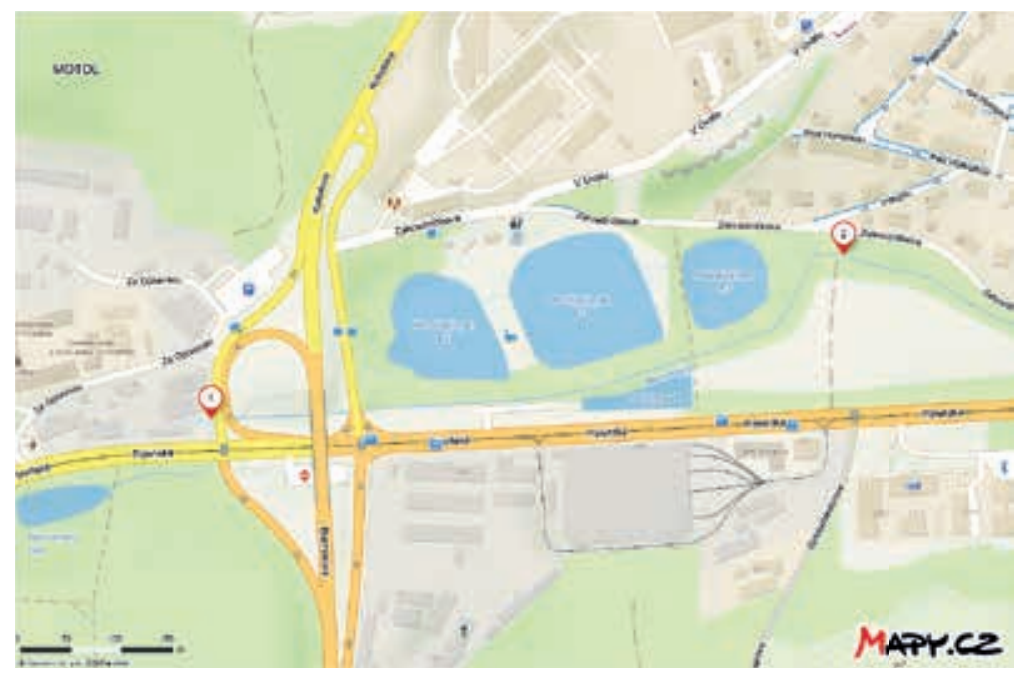

Obr. 1. Odběrová místa, Motolský potok, nádrže R1-R3; 1 - př́tok, 2 - odtok

Fig. 1. Sampling sites, Motolský stream, R1-R3 retention tanks; 1 - inflow, 2 - outflow

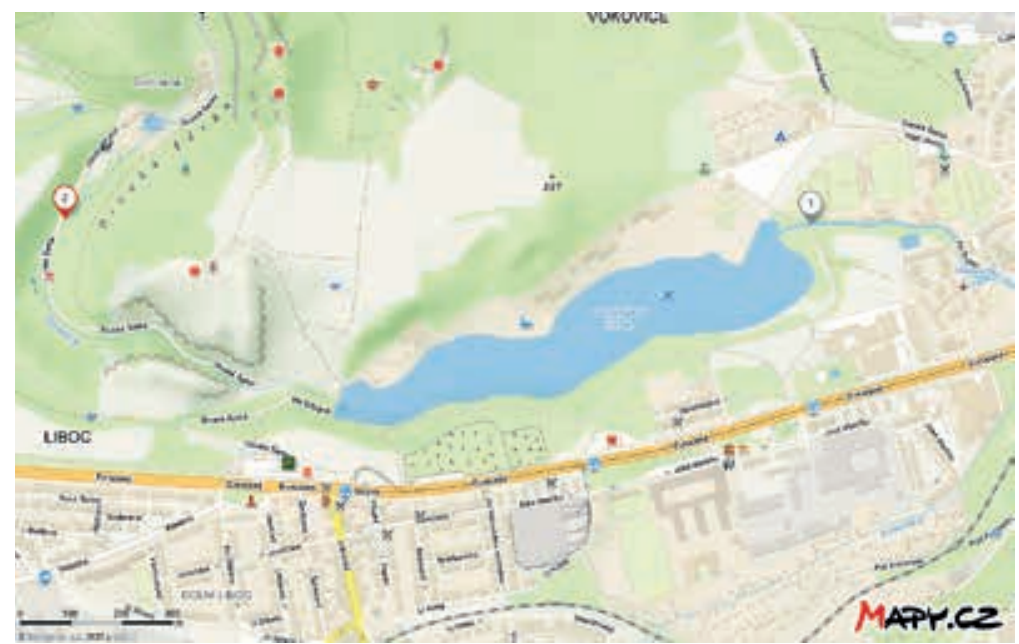

Obr. 2. Odběrová místa, Litovicko-Šárecký potok, nádrž Džbán; 1 - přítok, 2 - odtok Fig. 2. Sampling sites, Litovicko-Šárecký stream, Džbán water reservoir; 1 - inflow, 2- outflow 


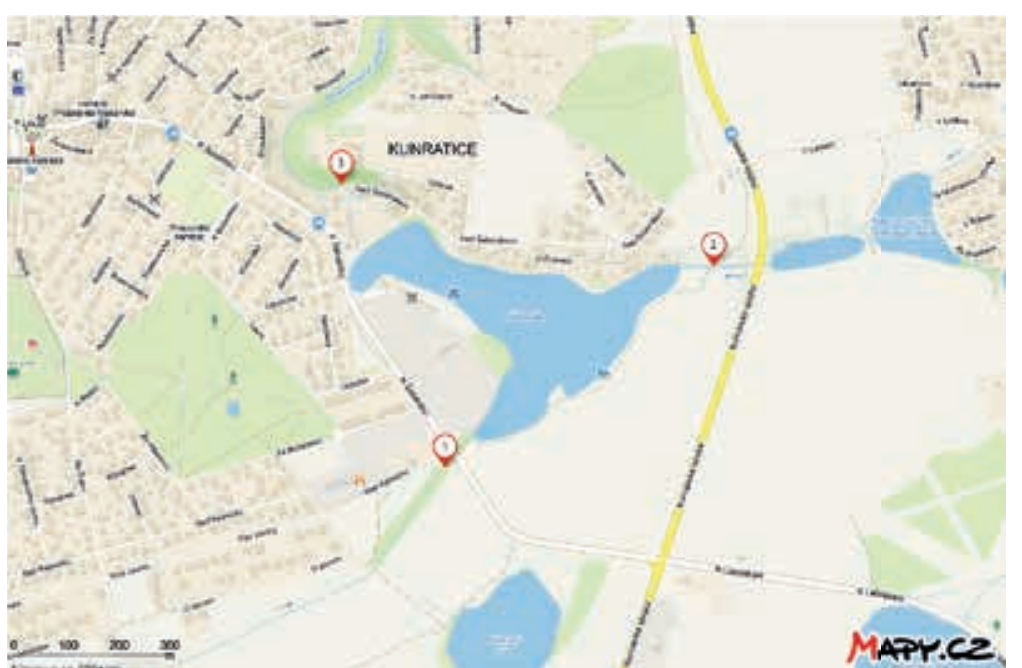

Obr. 3. Odběrová místa, rybník Šeberák; 1 - prítok Vestecký potok, 2 - př́tok Kunratický potok, 3 - odtok

Fig. 3. Sampling sites, Šeberák fishpond; 1 - Vestecký stream inflow, 2 - Kunratický stream inflow, 3 - outflow

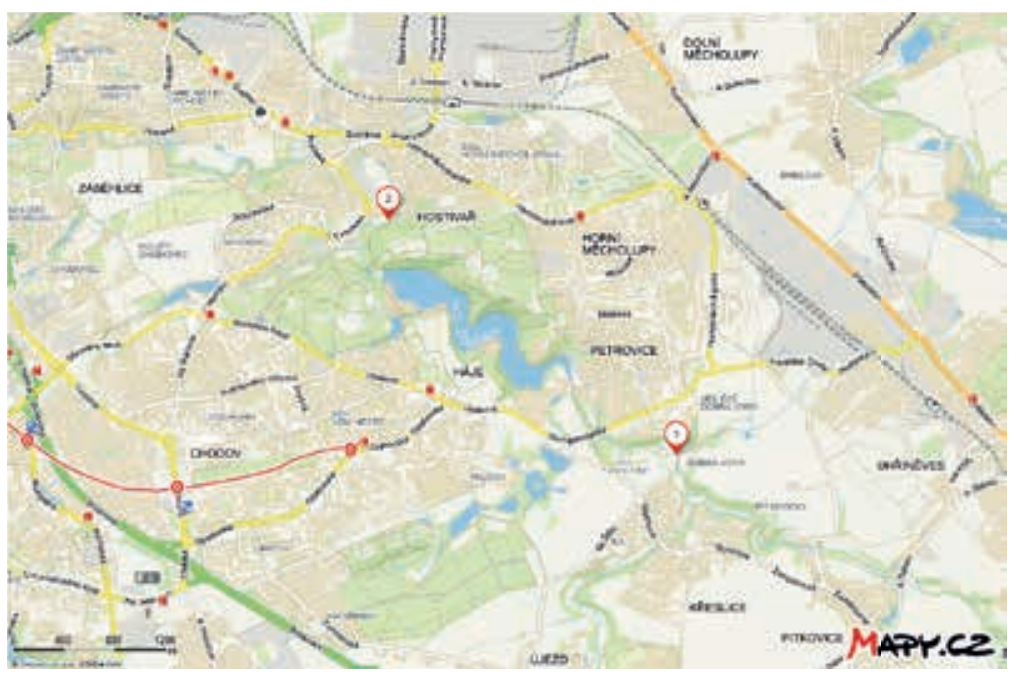

Obr. 4. Odběrová místa, Botič, nádrž Hostivař; 1 - prítok, 2 - odtok

Fig. 4. Sampling sites, Botič stream, Hostivař water reservoir; 1 - inflow, 2 - outflow

\section{Charakteristika lokalit}

— BF 1 (Motolský potok, přitok do retenčních nádrží R1-R3): „"natěsno" vydlážděné koryto, v podstatě bez sedimentu, občas téměř bez vody (obr. 5),

- BF 2 (Motolský potok, odtok z retenčních nádrží R1-R3): vydlážděné koryto, na dně písek a menší kameny, trvale zavodněné (obr. 6),

— BF 3 (Litovicko-Šárecký potok, přitok do nádrže Džbán): vydlážděné koryto, na dně písek a kameny (i větší), trvale zavodněné (obr. 7),

— BF 4 (Litovicko-Šárecký potok, odtok z nádrže Džbán): prírodní koryto, písek, kameny rưzné velikosti, ponořená makrovegetace (obr. 8). Vzhledem ke kvalitě vody odtoku z hypolimnia nádrže Džbán, zvláště koncem léta $\left(\mathrm{H}_{2} \mathrm{~S}\right.$, bakteriální povlaky dna - obr. 9), nebyly vzorky fytobentosu a makrozoobentosu odebírány prímo pod nádrží; odběr byl posunut cca 500 m níže,
- BF 5 (Vestecký potok, levý prítok do rybníka Šeberák):

naprímený potok, nedlážděný, na dně většinou bahno z okolních polí, občas písek, kameny vzácné, pouze drobnější valounky (obr. 10),

- BF 6 (Kunratický potok, pravý prítok do rybníka Šeberák): nehodnocen - po celé sledované období do rybníka Šeberák voda neodtékala, profil se změnil na mokřad (obr. 11),

- BF 7 (Kunratický potok, odtok z rybníka Šeberák) umělé koryto, vydlážděné, na dně většinou jemné bahno z rybníka Šeberák zvláště během vypouštění a odstraňování sedimentů v roce 2019 (obr. 12),

- BF 8 (Botič, prítok do nádrže Hostivař): prírodní koryto, na dně písek, drobnější i větší kameny (obr. 13),

- BF 9 (Botič, odtok z nádrže Hostivař): prírodní koryto, vtok do prírodní rezervace Meandry Botiče (obr. 14).

\section{METODIKA ODBĚRŮ A ANALÝZ VZORKU゚}

\section{Fytobentos}

Vzorky fytobentosu byly odebírány z charakteristického úseku toku vždy třikrát ročně (duben, srpen, listopad). Odběry i analýza druhového složení byly provedeny $v$ souladu se standardními metodami podle ČSN [3-6], v každém vzorku byly vyhodnoceny relativní abundance jednotlivých druhư řas podle základní stupnice, viz [5].

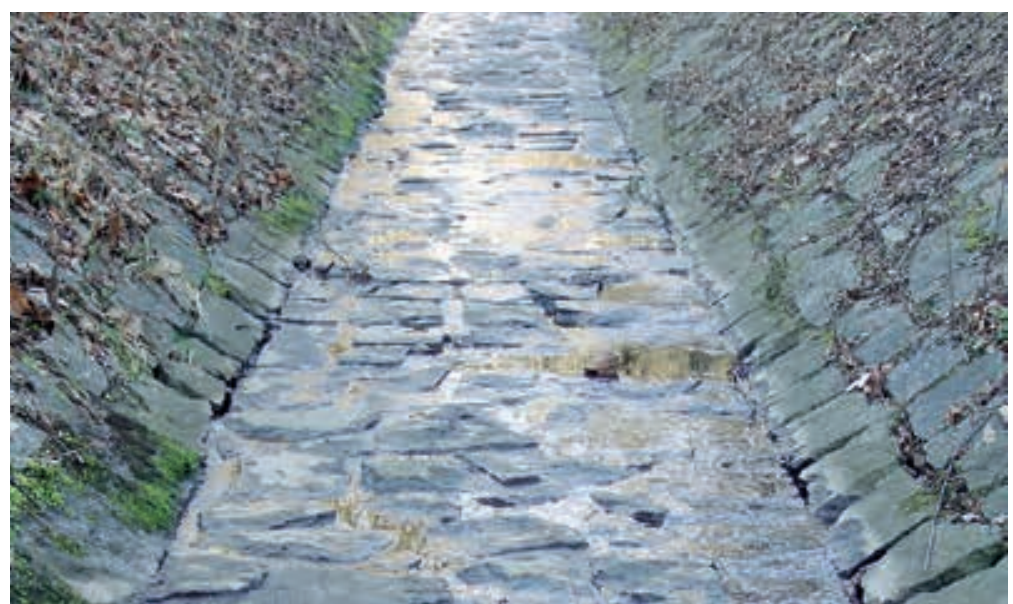

Obr. 5. Profil BF 1, Motolský potok, př́tok do retenčních nádrží R1-R3

Fig. 5. BF 1 profile; Motolský stream, inflow into the R1-R3 retention tanks

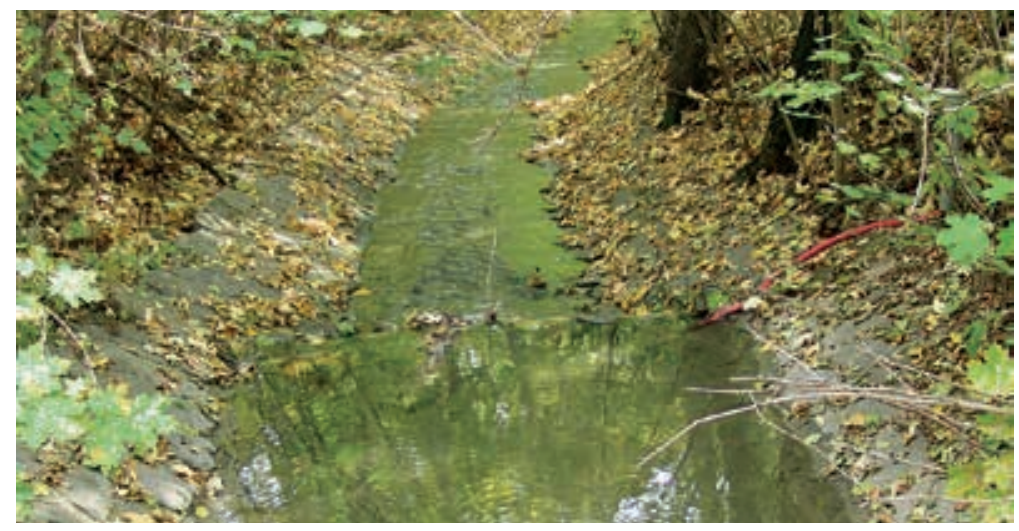

Obr. 6. Profil BF 2, Motolský potok, odtok z retenčních nádrží R1-R3

Fig. 6. BF 2 profile; Motolský stream, outflow from the R1-R3 retention tanks 

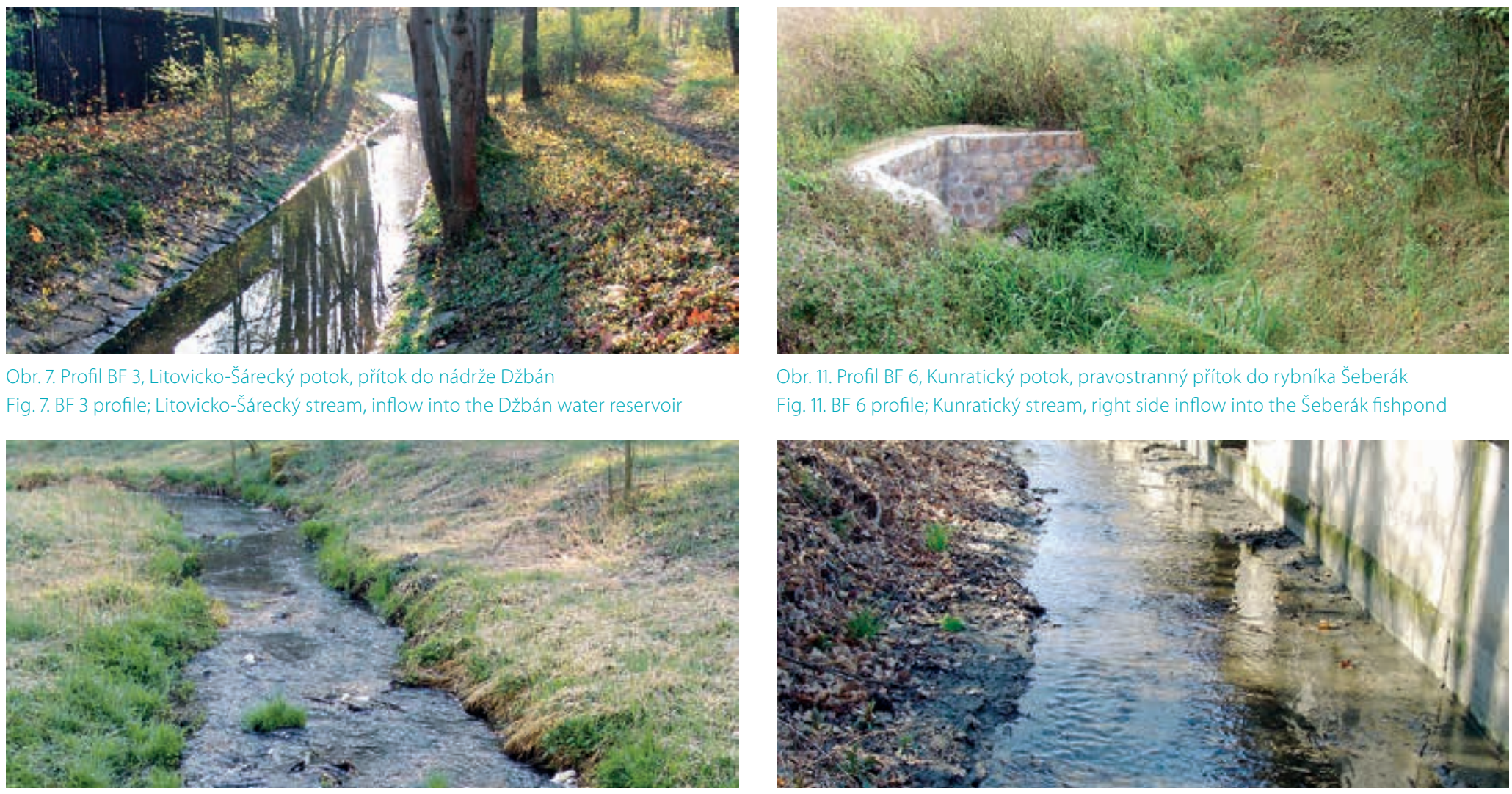

stream, cca $500 \mathrm{~m}$ under the outflow from
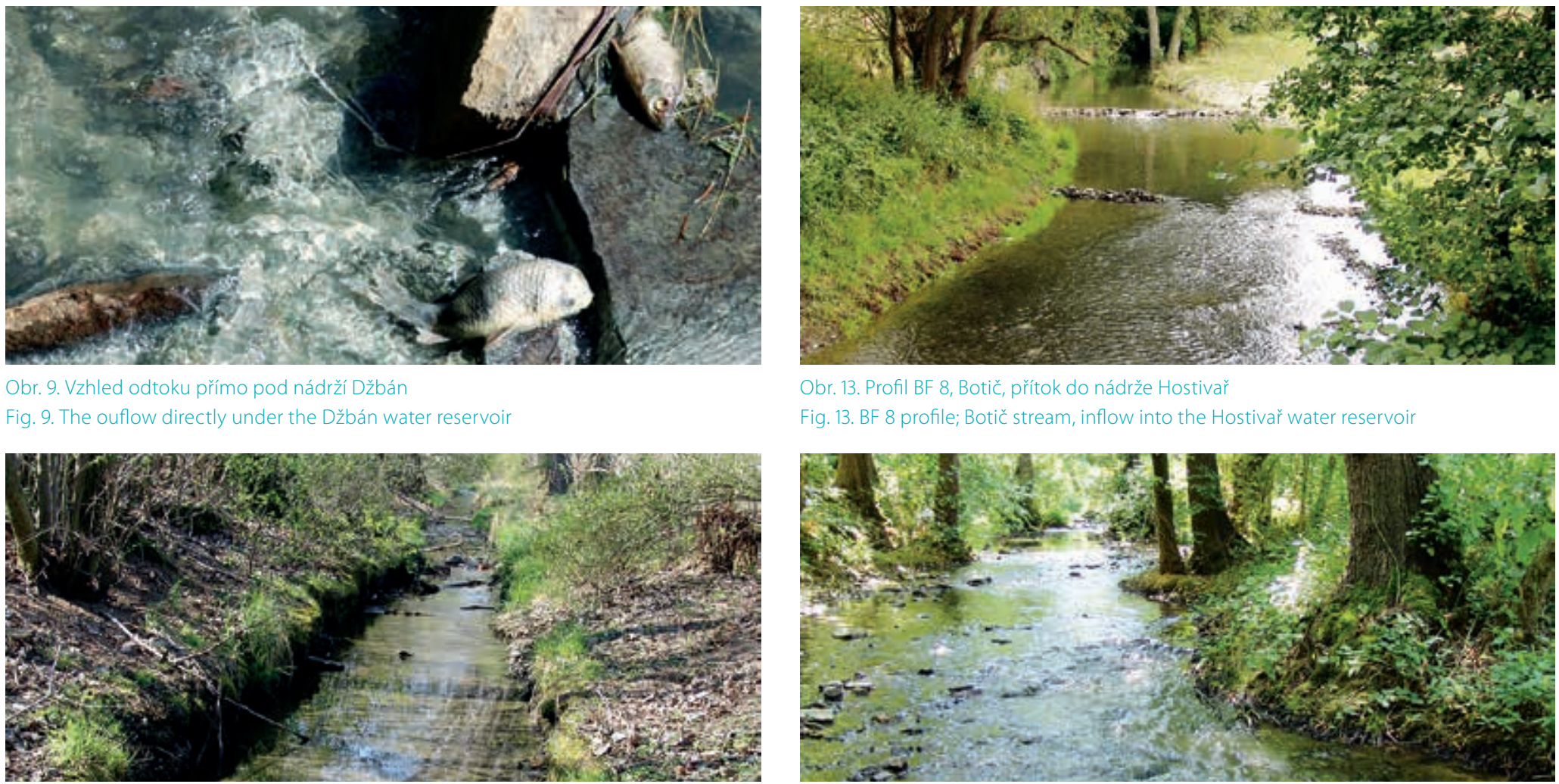

Obr. 10. Profil BE 5, Vestecký potok, levostranný prútok do rybníka Seberák

Obr. 14 Profil BF 9 Botič odtok z nádrže Hostivař 
Tabulka 1. Koncentrace fosforu v profilech

Table 1. Phosphorus concentrations in profiles

\begin{tabular}{|c|c|c|c|c|c|c|}
\hline BF 1: & R1 & BF 2: & R3 & BF 3: $r$ & bán & BF 4: odtok Džbán \\
\hline$P_{\text {celk }} \mathrm{mg} / \mathrm{I}$ & $\begin{array}{l}\mathrm{P}_{-} \mathrm{PO}_{4} \\
\mathrm{mg} / \mathrm{I}\end{array}$ & $P_{\text {celk }} m g / I$ & $\begin{array}{l}\mathrm{P}_{-} \mathrm{PO}_{4} \\
\mathrm{mg} / \mathrm{I}\end{array}$ & $P_{\text {celk }} \mathbf{m g} / \mathrm{I}$ & $\begin{array}{l}\mathrm{P}_{-} \mathrm{PO}_{4} \\
\mathrm{mg} / \mathrm{I}\end{array}$ & $P_{\text {celk }} m g / I$ \\
\hline
\end{tabular}

\section{8}

prům. 0,092

0,033

min. 0,056

\begin{tabular}{lll|l}
\hline $\boldsymbol{m a x}$. & 0,240 & 0,055 & 0,760 \\
\hline $\mathbf{n}$ & 8 & 8 & 9
\end{tabular}

\section{9}

\begin{tabular}{|c|c|c|c|c|c|c|c|c|}
\hline prům. & 0,092 & 0,029 & 0,198 & 0,048 & 0,446 & 0,279 & 0,458 & 0,312 \\
\hline min. & 0,059 & 0,013 & 0,057 & 0,013 & 0,244 & 0,042 & 0,131 & 0,013 \\
\hline $\max$. & 0,140 & 0,053 & 0,420 & 0,110 & 0,973 & 0,795 & 1,34 & 1,18 \\
\hline $\mathbf{n}$ & 7 & 7 & 6 & 6 & 9 & 9 & 8 & 8 \\
\hline Třída & II. & & IV. & & V. & & V. & \\
\hline
\end{tabular}

\begin{tabular}{|c|c|c|c|c|c|c|c|}
\hline \multirow[t]{3}{*}{ Trída } & \multicolumn{2}{|l|}{ II. } & \multicolumn{2}{|l|}{ IV. } & \multicolumn{2}{|l|}{ V. } & \multirow{2}{*}{ BF 9: odtok Hostivař } \\
\hline & \multicolumn{2}{|c|}{ BF 5: přítok Šeberák } & \multicolumn{2}{|c|}{ BF 7: odtok Šeberák } & \multicolumn{2}{|c|}{ BF 8: přítok Hostivař } & \\
\hline & $P_{\text {celk }} \mathbf{m g} / \mathbf{I}$ & $\begin{array}{l}\mathrm{P}_{-} \mathrm{PO}_{4} \\
\mathrm{mg} / \mathrm{I}\end{array}$ & $P_{\text {celk }} \mathbf{m g} / \mathbf{I}$ & $\begin{array}{l}\mathrm{P}_{-} \mathrm{PO}_{4} \\
\mathrm{mg} / \mathrm{I}\end{array}$ & $P_{\text {celk }} \mathrm{mg} / \mathrm{I}$ & $\begin{array}{l}\mathrm{P}_{-} \mathrm{PO}_{4} \\
\mathrm{mg} / \mathrm{I}\end{array}$ & $P_{\text {celk }} \mathbf{m g} / \mathbf{I}$ \\
\hline 2018 & & & & & & & (data [12]) \\
\hline prům. & 0,835 & 0,513 & 0,449 & 0,158 & 0,447 & 0,289 & 0,368 \\
\hline $\min$. & 0,211 & 0,081 & 0,127 & 0,013 & 0,206 & 0,013 & 0,105 \\
\hline $\max$. & 2,01 & 1,70 & 1,190 & 0,356 & 0,804 & 0,506 & 1,1 \\
\hline $\mathbf{n}$ & 9 & 9 & 8 & 8 & 9 & 9 & 6 \\
\hline 2019 & & & & & & & (01-07, data [12]) \\
\hline prům. & 0,4 & 0,225 & 0,461 & 0,108 & 0,388 & 0,287 & 0,114 \\
\hline $\min$. & 0,181 & 0,054 & 0,122 & 0,013 & 0,194 & 0,076 & 0,07 \\
\hline $\max$. & 0,703 & 0,58 & 1,36 & 0,232 & 0,684 & 0,545 & 0,158 \\
\hline $\mathbf{n}$ & 9 & 9 & 9 & 9 & 9 & 9 & 4 \\
\hline Třída & V. & & V. & & V. & & \\
\hline
\end{tabular}




\section{Makrozoobentos}

Vzorky makrozoobentosu byly odebírány $v$ souladu s metodikou MŽP a př́slušnými platnými normami [7, 8]. Vzorky z jednotlivých profilů byly odebírány metodou "kick samples" dvakrát ročně (duben, listopad) z charakteristického úseku toku. Z odebraného vzorku byly (po opláchnutí vodou z lokality) odstraněny zachycené velké částice (listí, makrofyta, ...). Vzorek byl následně převeden do vzorkovnice a nafixován etanolem. V laboratoři byly pod binokulární lupou odebrané vzorky podrobně prohlédnuty, přitomné organismy převedeny do $70 \%$ etanolu a určeny (binokulární lupa, mikroskop).

Ve vzorcích byl stanoven celkový počet organismů v odebraném standardním vzorku [7, 8], saprobní index [9] a index diverzity Shannon-Weaver [10].

\section{VÝSLEDKY}

\section{Koncentrace fosforu v jednotlivých profilech}

$\checkmark$ tabulce 1 jsou uvedeny prưměrné, maximální a minimální hodnoty koncentrací celkového $\left(\mathrm{P}_{\text {celk }}\right)$, a fosforečnanového $\left(\mathrm{P}-\mathrm{PO}_{4}\right)$ fosforu pro jednotlivé profily odběru vzorků. Vysoké koncentrace $P_{\text {celk }}$ radí vodu profilů až do IV.-V. tř́dy jakosti podle ČSN 757221 [11]. Výjimkou je profil BF 1 - př́tok do retenční nádrže R1 (horní tok Motolského potoka). Data pro profil BF 9 - odtok z nádrže Hostivař pro rok 2018 jsou prevzata z [12].

\section{Fytobentos}

\section{KVALITATIVNÍ SLOŽENÍ FYTOBENTOSU}

Kvalitativní složení fytobentosu bylo ve všech sledovaných profilech podobné, se zřetelnou dominancí dvou hlavních skupin, rozsivek (Bacillariophyceae) a zelených řas z třídy Chlorophyceae. Ve druhém prípadě se ovšem na rozdíl od rozsivek nejedná o typické bentické řasy, nýbrž o řasy planktonní, které byly do sledovaných profilů zaneseny z přilehlých stojatých vod (rybníků či vodních nádrží). S ohledem na to, že se jedná o typickou letní složku fytoplanktonu, hojněji a ve vyšší abundanci se vyskytovaly až v rámci letních a podzimních odběrů.

Z rozsivek dominovaly především velmi hojné druhy charakteristické pro vody s vyšší či střední trofí, často tolerantní ke znečištění, či druhy se širokou ekologickou amplitudou, jmenovitě zejména Diatoma vulgaris, Navicula lanceolata, Navicula tripunctata, Synedra ulna, Navicula gregaria, Melosira varians, Nitzschia acicularis atd. Ze zelených řas zejména běžní zástupci eutrofních vod z rodů Desmodesmus, Pediastrum s.l., Coelastrum, Actinastrum, Monoraphidium atd. Ostatní skupiny řas (včetně sinic) byly vesměs zastoupeny pouze minoritně a až na výjimky se jejich zástupci nepodíleli na složení společenstev významně ani kvantitativně. Těmito výjimkami byl především hojnější výskyt (oproti ostatním profilům) některých vláknitých řas (zejména Audouinella sp. a Cladophora glomerata) na profilech BF 4, BF 5 a v menší míře také na profilech BF 8 a BF 9.

I pres poměrně vysokou celkovou druhovou diverzitu zaznamenanou na jednotlivých profilech (podrobněji viz níže) nebyly ve vzorcích nalezeny téměř žádné vzácné druhy, za zmínku stojí zejména nález vzácného bičíkovce Tetraselmis cordiformis na profilech BF 5, BF 7 a BF 8 či nález pozoruhodné, v ČR roztroušeně se vyskytující haptofytní rasy Hymenomonas roseola na profilech $\mathrm{BF} 3$ a BF 8.

\section{KVANTITATIVNÍ SLOŽENÍ FYTOBENTOSU}

Celková druhová diverzita byla na všech hodnocených profilech velmi podobná, pohybovala se mezi 124 (profil BF 7) a 150 druhy (profil BF 2). Jedinou výjimkou byl profil BF $1 \mathrm{~s}$ celkem 70 druhy, u něj byla ovšem tato hodnota výrazně ovlivněna vyschnutím od léta 2018 do jara 2019, hodnoceny byly tudíž vzorky pouze ze tří odběrů. Navíc bylo i na nízké diverzitě zejména letního vzorku z roku 2019 a extrémně nízké abundanci většiny řas patrné, že se společenstva fytobentosu teprve vzpamatovávají z dlouhotrvajícího vyschnutí. Zhruba srovnatelná byla u všech profilů i průměrná druhová diverzita na vzorek, která se pohybovala (s výjimkou profilu BF 1 se 37 druhy) od 41 druhů (profil BF 5) do 59 druhů (profil BF 2). Jak už bylo ovšem zmíněno výše, druhové složení společenstev fytobentosu bylo zejména $v$ letním a podzimním období výrazně ovlivněno splavením planktonních zástupců z přilehlých stojatých vod, zmíněné rozdíly tedy nemají jednoznačnou vypovídací schopnost. Míra odlišnosti mezi jednotlivými lokalitami byla tedy do značné míry dána odlišností druhového složení letních vzorků, tj. v podstatě mírou ovlivnění jednotlivých profilů přilehlými stojatými vodami, z nichž byly na daná odběrová místa splaveny planktonní řasy a sinice (které byly určující složkou zmíněné odlišnosti), spiše než výraznějšími rozdíly $\checkmark$ prirozených společenstvech jejich fytobentosu.

\section{Makrozoobentos}

Výsledky stanovení makrozoobentosu v jednotlivých sledovaných profilech za období let 2018-2019 jsou uvedeny v tabulce 2. Výsledky jsou průměrnými hodnotami ukazatelů ze dvou (profil BF 1 - v listopadu 2018 a v dubnu 2019 byl bez vody), tří (profil BF 2 - v dubnu 2019 byl bez vody; profil BF 7 - v listopadu 2019 silně ovlivněn vysokým průtokem a množstvím sedimentu vzhledem k vypouštění rybníka Šeberák a odstraňování sedimentu v roce 2019) a čtyř odběrů (ostatní profily).

Tabulka 2. Charakteristiky společenstev makrozoobentosu ve sledovaných profilech (n: počet jedinců ve vzorku, Si: saprobní index, H: index diversity Shannon-Weaver) Table 2. Characteristics of macroinvertebrate communities in the studied profiles (n: number of individuals per sample, Si: saprobic index, H: Shannon-Weaver diversity index)

\begin{tabular}{lllll}
$\begin{array}{l}\text { Označení } \\
\text { profilu }\end{array}$ & Název profilu & $\mathbf{n}$ & Si & H \\
\hline BF 1 & Přítok R1-R3 & 99 & 2,61 & 1,72 \\
\hline BF $\mathbf{2}$ & Odtok R1-R3 & 425 & 2,43 & 2,31 \\
\hline BF 3 & Džbán př́tok & 411 & 2,51 & 2,45 \\
\hline BF 4 & Džbán odtok & 733 & 2,24 & 2,19 \\
\hline BF 5 & Šeberák př́tok, Vestecký & 616 & 2,43 & 2,31 \\
\hline BF 7 & Šeberák odtok & 383 & 2,71 & 2,31 \\
\hline BF 8 & Hostivař př́tok & 926 & 2,11 & 1,78 \\
\hline BF 9 & Hostivař odtok & 806 & 2,35 & 1,84
\end{tabular}

\section{KVALITATIVNÍ SLOŽENÍ MAKROZOOBENTOSU}

Kvalitativní složení makrozoobentosu bylo ve všech sledovaných profilech obdobné, lišilo se spíše poměrným zastoupením jednotlivých taxonů. Vždy byly ( $v$ různé míře) zastoupeni máloštětinatci (Oligochaeta - Tubificidae), pijavky (predevším Erpobdella octoculata), korýši Asellus aquaticus, měkkýši 
(většinou Pisidium sp. a Bythinia sp.), larvy Chironomidae, larvy chrostíků (hlavně Hydropsyche angustipennis), ve většině profilů i larvy jepic (především Baetis fuscatus) a časté byly i larvy muchniček (Simulium sp.).

$\checkmark$ některých profilech se vyskytovali (i ve značném množství) žahavci (nezmar - Hydra sp. - profily BF 2, BF 3, BF 4, BF 5); v menším množství larvy pakomárcovitých (Ceratopogonidae - profily BF 1, BF 3, BF 4, BF 5, BF 7), korýs Gammarus fossarum (profily BF 3, BF 4, BF 5, BF 7). Larvy i dospělci brouků (Coleoptera - Elmis sp.) se vyskytovali pouze v přirozených úsecích toků (profily BF 4, BF 8, BF 9). V profilech BF 3, BF 4, BF 9 byly ojediněle nalezeny larvy vážek (Odonata - Calopteryx sp., Coenagrion sp.), v profilech BF 4 a BF 8 dravé larvy chrostíků (Rhyacophila sp.) a v profilu BF 8 plž Ancylus fluviatilis.

\section{ABUNDANCE ORGANISMŮ - POČET \\ ORGANISMŮ NA STANDARDNÍ VZOREK}

Podle oživení Ize profily zařadit do několika skupin. Výrazně nejnižší oživení vykazoval profil BF 1 (Motolský potok, přitok do R1-R3) - vydlážděný, s velmi kolísajícím průtokem, občas bez vody (organismy pouze v mezerách mezi dlážděním). Jako nízkou lze charakterizovat i abundanci makrozoobentosu v profilu BF 7 - vydlážděné koryto, silně ovlivňované kolísajícím odtokem ze Šeberáku a zanášené jemnými rybničními sedimenty. Další skupinu tvoří profily BF 2, BF 3, také s vydlážděným korytem, ale s trvalým průtokem, na dně je přitomen sediment a kameny různé velikosti. Průměrná abundance (ve srovnání s ostatními sledovanými profily) byla v profilu BF 5 - např́mené koryto, nevydlážděné, na dně převážně jemný sediment (většinou splachy z okolních polí). Nejvyšší abundanci makrozoobentosu vykazují přirozené profily BF 4, BF 8, BF 9 (tabulka 2).

\section{SAPROBNÍ INDEX}

Hodnoty saprobního indexu odpovídají hydrologickým podmínkám a kvalitě vody potoků. Na úrovni alfa-mesosaprobity jsou profily BF 1, BF 3 a BF 7 (profil BF 7 - Si 2,71, nejhorší ze sledovaných - je ovlivněn podmínkami odtoku z rybníka Šeberák). Do stupně beta-mesosaprobita Ize zařadit ostatní profily - nejlepší je opět u přirozených toků v profilech BF 4, BF 8, BF 9 (tabulka 2).

\section{INDEX DIVERZITY}

Ve sledovaných lokalitách je nejnižší index diverzity (tj. relativně nejvyšší diverzita společenstva makrozoobentosu) v přirozených profilech BF 4 (LitovickoŠárecký potok pod nádrží Džbán), BF 8, BF 9 (Botič) a poněkud překvapivě v profilu BF 1 (Motolský potok, prítok do R1-R3). Na profilu BF 1 je to dáno poměrně rovnoměrným zastoupením taxonů při velmi nízkém celkovém počtu jedinců ve standardním vzorku (tabulka 2).

\section{ZÁVĚR}

Sledování kvality vody pražských potoků v letech 2018-2019, v jejichž povodí jsou prírodní koupaliště, zahrnovalo i sledování hydrobiologických ukazatelů: fytobentos a makrozoobentos. Vzorky byly na jednotlivých potocích odebírány $\checkmark$ profilech prítok a odtok těchto prírodních koupališt't.

Z výsledků vyplývá, že společenstvo makrozoobentosu vykazuje nejvyšší abundanci a druhovou diverzitu v potocích s nejpřirozenějšími morfologickými podmínkami (prírodní koryta potoků Litovicko-Šáreckého potoka pod nádrží Džbán a Botiče nad i pod nádrží Hostivař, tj. profily BF 4, BF 8, BF 9). I tato společenstva však při kombinaci vlivů prostředí (morfologie toku, kvalita vody, substrát dna apod.) svým stupněm saprobity odpovídají horší beta-mesosaprobitě. Naopak ve společenstvech fytobentosu žádný významnější rozdíl (až na hojnější výskyt vláknitých forem v přírodních korytech) mezi prírozenými a umělými profily zjištěn nebyl. Pro vesměs přizpůsobivé řasy (zejména rozsivky), které v uvedených profilech dominují, se tedy zdá být klíčovým faktorem spíše chemismus vody než např. mikrotopografie dna.
Vypouštění vody z hypolimnia nádrže Džbán koncem léta výrazně ovlivňuje úsek Litovicko-Šáreckého potoka pod výpustí (obr. 9). Z tohoto důvodu byl odběr vzorku fytobentosu a makrozoobentosu posunut několik set metrů po proudu (viz výše).

Je zřejmé, že hlavní vliv na společenstva fytobentosu a makrozoobentosu ve sledovaných tocích má (vedle vlastní morfologie toku) i trvalý a vysoký prísun živin (zvláště P). Při předpokládané budoucí revitalizaci regulovaných a vydlážděných potokủ bude nutno zahrnout i úpravu jejich morfologie a substrátu dna a zároveň věnovat značnou pozornost kvalitě přitékající vody.

\section{Poděkování}

Přispěvek vznikl za podpory projektu CZ.07.1.02/0.0/0.0/16_040/0000382: Rekreačni potenciál vody v Praze - stav a výhledy; rešeného v rámci operačního programu Praha - pól rưstu Il.

\section{Literatura}

[1] DESORTOVÁ, B., HAVEL, L. a ŠŤASTNÝ, J. Kvalita vody pražských potoků. Část 1: Motolský a Litovický potok. VTEI, roč. 61, č. 2, s. 20-26. ISSN 0322-8916.

[2] HAVEL, L., DESORTOVÁ, B. a ŠŤASTNÝ, J. Kvalita vody pražských potoků. Část 2: přítoky do rybníka Šeberák a přehradní nádrže Hostivař. VTEI, roč. 61, číslo 3, s. 6-13. ISSN 0322-8916.

[3] ČSN 75 7715: Kvalita vod - Biologický rozbor: Stanovení nárostů. Praha, 2015.

[4] ČSN EN 14407 (75 7722): Kvalita vod - Návod pro identifikaci a kvantifikaci bentických rozsivek z vodních toků a pro interpretaci dat. Praha, 2014.

[5] ČSN EN 15708 (757719): Jakost vod - Návod pro sledování, odběr vzorků a laboratorní analýzu fytobentosu v mělkých tekoucích vodách. Praha, 2010.

[6] Metodika odběru a zpracování vzorků fytobentosu tekoucích vod. Metodika MŽP ČR, 2006.

[7] NĚMEJCOVÁ, D. a KOKEŠ, J. Metodika odběru a zpracování vzorků makrozoobentosu metodou PERLA. Praha, MŽP ČR 2006.

[8] ČSN 75 7701: Jakost vod - Metodika odběru a zpracování vzorků makrozoobentosu tekoucích vod metodou PERLA. Praha, 2007.

[9] ČSN 75 7716: Jakost vod - Biologický rozbor: Stanovení saprobního indexu. Praha, 1998. [10] ODUM, E.P. Základy ekologie. Academia Praha, 1977.

[11] ČSN 75 7221: Kvalita vod - Klasifikace kvality povrchových vod. Praha, 2017.

[12] Botič. Pražská příroda [online]. Hlavní město Praha, 2013 [cit. 20. 04. 2020]. Dostupné z: www.praha-priroda.cz/odborna-verejnost/kvalita-vody/kvalita-vody-ve-vodnich-tocich/botic/

\section{Autoři}

RNDr. Ladislav Havel, CSc.

凶ladislav.havel@vuv.cz

\section{Mgr. Jan Št'astný, Ph.D.}

凶jan.stastny@vuv.cz

RNDr. Blanka Desortová, CSc.

凶blanka.desortova@vuv.cz

Výzkumný ústav vodohospodářský T. G. Masaryka, v. v. i.

Př́spěvek prošel lektorským řizením.

DOI: 10.46555 /VTEI.2020.03.003 


\section{THE PHYTOBENTHOS AND MACROINVER- TEBRATES OF PRAGUE STREAMS WITH NATURAL PUBLIC BATHING PLACES}

\section{HAVEL, L.; STASTNY, J.; DESORTOVA, B.}

TGM Water Research Institute, p.r.i.

Keywords: Prague streams - natural public bathing

places - phytobenthos - macroinvertebrates

The water quality monitoring of selected streams in Prague (which harbour in their catchment area natural bathing places) during 2018-2019 included also the monitoring of two hydrobiological indicators; the phytobenthos and macroinvertebrates communities. The samples were taken in every particular stream near the inflow into and outflow from the natural bathing places, respectively.

The results indicate that the macroinvertebrates communities display the highest abundance as well as species diversity in streams with the most natural conditions (natural stream beds of Litovicko-Šárecký stream under the Džbán water reservoir as well of Botič stream above and under the Hostivař water reservoir, i.e. in profiles BF 4, BF 8 and BF 9). But even these communities, considering the combination of various environmental impacts (stream morphology, water quality, bed substrate, etc.) correspond only to worse beta-mesosaprobity. On the other hand, there was no significant difference between the natural and artificial profiles, as regards the phytobenthos communities (except of more abundant occurrence of filamentous forms in natural profiles). Consequently, for the mostly adaptable algae, which dominate them (particularly diatoms) the water, chemism seems to be of higher importance than e.g. the streambed microtopography.

Should a revitalization of the altered and paved streams proceed in future, it should comprise the modification of their morphology and of the streambed, and their water quality should be taken into account as well. 